Biol. Stud. 2020: 14(3); 49-64 • DOI: https://doi.org/10.30970/sbi.1403.627

www.http://publications.Inu.edu.ua/journals/index.php/biology

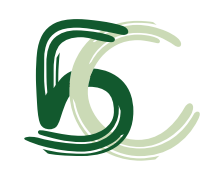

UDC: $579.61: 616.5$

\title{
DETERMINATION OF BIOFILM FORMATION AND ASSOCIATED GENE DETECTION IN STAPHYLOCOCCUS GENUS ISOLATED FROM THE ORAL CAVITY UNDER INFLAMMATORY PERIODONTAL DISEASES
}

\author{
M. V. Kryvtsova 1*, J. Király@2, J. Koščová@2, \\ Ye. Ya. Kostenko ${ }^{3}$, R. V. Bubnov ${ }^{4}$, M. Ya. Spivak ${ }^{4}$ \\ ${ }^{1}$ Uzhhorod National University, Biological Faculty, Department of Genetics, Plant Physiology \\ and Microbiology, 32, Voloshyn St., Uzhhorod 88000, Ukraine \\ ${ }^{2}$ University of Veterinary Medicine and Pharmacy in Košice \\ Department of Microbiology and Immunology, Institute of Microbiology and Gnotobiology \\ 73, Komenský St., 04181 Košice, Slovakia \\ ${ }^{3}$ Uzhhorod National University, Biological Faculty, Faculty of Dentistry \\ Department of Orthopaedic Dentistry, 16, Universytetska St., 88000 Uzhhorod, Ukraine \\ ${ }^{4}$ Zabolotny Institute of Microbiology and Virology, NAS of Ukraine \\ 154, Zabolotnyi St., Kyiv 03680, Ukraine \\ ${ }^{*}$ Corresponding author: e-mail: maryna.krivcova@uzhnu.edu.ua
}

Kryvtsova M. V., Király J., Koščová J., Kostenko Ye. Ya., Bubnov R.V., Spivak M. Ya. Determination of biofilm formation and associated gene detection in Staphylococcus genus isolated from the oral cavity under inflammatory periodontal diseases. Studia Biologica, 2020: 14(3); 49-64 • DOI: https://doi.org/10.30970/sbi.1403.627

Background. Inflammatory periodontal diseases, including chronic periodontitis, are accompanied by a chronic persisting inflammatory process. The latter process and biofilm-forming potential are the factors that contribute to the formation of antibiotic-resistant microorganism strains. The purpose of our work was to study the biofilm-forming ability of antibiotic-resistant biofilm-forming Staphylococcus genus bacteria isolated from the oral cavities of patients suffering from periodontitis, and check the presence of the genes associated with biofilm formation in these bacteria.

Material and methods. Isolates were obtained from patients suffering from chronic periodontitis using differentially diagnostic nutrient media. Chemotaxonomic identification of the antibiotic-resistant isolates was performed on the Microflex LT device. Biofilm-forming potential was studied in plastic Petri dishes by spectrophotometric method. The antibiotic sensitivity of the bacteria and microscopic fungi was identified by the disc diffusion method. The presence of $i c a A$, icaD, icaC, icaB, agrA, srt $A$ genes was

(C) 2020 M. V. Kryvtsova et al.; Published by the Ivan Franko National University of Lviv on behalf of Біологічні Студії / Studia Biologica. This is an Open Access article distributed under the terms of the Creative Commons Attribution License (http://www.budapestopenaccessinitiative.org/ and Creative Commons Attribution 4.0 License), which permits unrestricted reuse, distribution, and reproduction in any medium, provided the original work is properly cited.

ISSN 1996-4536 (print) • ISSN 2311-0783 (on-line) • Біологічні Студії / Studia Biologica • 2020 • Том 14/№3 • C. 49-64 
detected in two multiplex polymerase chain reactions (mPCR). 16S rRNA gene and icaR genes were amplified in a separate PCR.

Results. Opportunistic microbial associations dominate in the microbiom of the oral cavity under conditions of periodontitis; besides, in the majority of cases, Staphylococcus genus bacteria were present in associations. In $73 \%(131 / 180)$ of cases, bacteria from Staphylococcus genus represented by six species - S. aureus, S. haemolyticus, S. saprophyticus, S. epidermidis, S. xelosus, and S. hominis were isolated from the nidus during the inflammatory process. From the oral cavities of the patients with inflammatory periodontitis, 51 biofilm-forming strains of S. aureus, 29 strains of S. haemolyticus, 12 strains of $S$. saprophyticus, and 12 strains of $S$. epidermidis were isolated. It was established that antibiotic-resistant isolates of $S$. aureus possess the genetic determinants which are now believed to be connected with ica $A$, icaC, icaB icaA, icaR, agrA, and srtA biofilm-forming potential. Two non-biofilm forming strains of $S$. aureus were proven to lack the genes responsible for the biofilm-forming ability.

Conclusion: It has been established that microbial associations with a prevailing share of Staphylococcus genus bacteria, most of which have a biofilm-forming potential, dominate in the microbiom of the oral cavity under conditions of periodontitis.

Keywords: antibiotic resistance, microbial associations, Staphylococcus genus bacteria, biofilm formation

\section{INTRODUCTION}

The rapid development of microorganisms' resistance to antibiotics is a challenging issue in contemporary biology, medicine and ecology. The problem of antibiotic resistance appeared as soon as the first antibiotics were synthesized; however, during the recent several decades it has turned into a menacing socio-economic issue [2, 11, 23]. Microorganisms resistant to several antibacterial medical preparations arise a special concern. Multiresistant microorganisms (MRM) are mainly bacteria resistant to the action of one or several antibiotic classes. Staphylococcus genus bacteria occupy top positions in the formation of chronic persisting inflammatory diseases. With that said, especially dangerous are bacteria of the given genus that are resistant to methicillin (oxacillin) and demonstrate multiple resistance to antibiotics $[5,8]$. Staphylococcus strains resistant to antibiotics are, as a rule, agents of hospital infections. The role of coagulase-negative staphylococcus species in the formation of opportunistic infections and their multiple resistance to antimicrobial preparations have also been established [25, 27]. Today, the assertion that microorganisms exist in the form of biofilms - organized communities of microorganisms consisting of both actively functioning and dormant cells confined in the extracellular matrix - is a proven fact $[4,17]$. Studies have shown that $91 \%$ of the isolates from the oral cavity have a biofilm-forming potential. The frequency of detection of biofilm-forming properties among antibiotic resistant isolates is high.

Chronic periodontitis is a multifactorial disease, pathogenesis of which includes a number of inflammatory and dystrophic-inflammatory processes causing disbalance between the aggression factors (periodontopathogens) and organism protection factors, viz. of the oral cavity and the periodontal complex [12]. At the initial stages of an inflammatory process in periodontal tissues, the infection factors play the key role. The listed representatives of the oral cavity microbiota belong to periodontopathogens: Porphyromonas gingivalis, Actinobacillus actinomycetemcomitans, Bacteroides forsythus,

ISSN 1996-4536 (print) • ISSN 2311-0783 (on-line) • Біологічні Студії / Studia Biologica • 2020 • Том 14/№3 • C. 49-64 
Prevotella intermedia, Campylobacter rectus, Eikenella corrodens, and Fusobacterium nucleatum. At the initial stages of periodontitis, significant disorders of local immunity of periodontal tissues are observed accompanied by the action of such anaerobic Gramnegative bacteria as Aggregatibacter actinomycetemcomitans, Porphyromonas gingivalis, Prevotella intermedia and Tannerella forsythensis. These bacteria take part in the formation of periodontal (gingival) pocket, destruction of the connective tissue, alveolar bone resorption (alveoloclasia), etc. The formation of inflammatory infiltrate is accompanied by various immunopathologies $[4,6,20]$.

Apart from that, complications and relapses of periodontal inflammatory diseases, including periodontitis, may be caused by the transformation of the microbial coenosis and domination of opportunistic microorganisms in the microbial associations of the oral cavity. The colonization of the mucous membrane with transitory and allochthonous representatives of the microbiota, which are often characterized by multiple resistance to antibiotics, leads to continuous recurrence and a chronic course of the inflammatory process. A number of authors consider periodontitis as an opportunistic infection accompanied by the presence of opportunistic and pathogenic bacteria in the oral cavity [4].

At the same time, the continuously growing tendency to form antibiotic resistance, especially when opportunistic microbiota are part of the biofilm, explains the need to constantly monitor the circulation of polyantibiotic-resistant isolates [22], analyze the effectiveness of antibacterial preparations, and develop new complex approaches and correction techniques with regard to the oral cavity microbiota affected by an inflammatory process.

The purpose of our work was to study the biofilm-forming ability of antibiotic-resistant biofilm-forming Staphylococcus genus bacteria isolated from the oral cavities of patients suffering from periodontitis, and the presence of the genes associated with biofilm formation in these bacteria.

\section{MATERIALS AND METHODS}

The level of microorganisms' resistance to antimicrobial preparations was examined under the persisting chronic inflammatory process (chronic generalized periodontitis). The study was conducted on the basis of the University of Dentistry. The biological material was taken from the oral cavity of human patients suffering from chronic generalized periodontitis at stages III and IV. The material for the study was taken from 180 patients of both genders aged from 35 to 65 . The material was obtained from the nidus of the inflammatory process - the periodontal pockets - using a sterile transport system (a test-tube with gel and an applicator for biological liquids produced by FLmedical, Italy). The mucous membrane possessed the following features of an inflammatory process: hyperemia, angiostaxis, and release of serous and purulent exudate. Patients with no signs of periodontitis and inflammatory periodontal processes $(n=50)$ formed the control group. The material was plated according to Gold onto the following nutrient media: Sabouraund Dextrose Agar, HiCrome ${ }^{\mathrm{TM}}$ Candida Differential Agar (Himedia) for cultivation of microscopic fungi; blood agar - for haemolytic microflora, in particular Streptococcus and Neisseria genera bacteria; Endo and Ploskoreva agar (Farmaktiv, Ukraine) - for Enterobacteriaceae genera bacteria; Mannitol Salt Agar (Biolif-Italia) - for Staphylococcus genus bacteria; Enterococci were identified with Bile esculin agar (Biolif-Italia). We identified the bacteria and yeasts based on macromorphology, micromorphology, physiological and biochemical tests using ENTERO-test, STREPTO-test, and STAPHYLO-test

ISSN 1996-4536 (print) •ISSN 2311-0783 (on-line) • Біологічні Студії / Studia Biologica • 2020 • Том 14/№3 • C. 49-64 
manufactured by Erba Lachema. The chemotaxonomic identification of the antibioticresistant isolates was performed on the Microflex LT device (Bruker Daltonics Gmb, Leipzig, Germany), Flex Control (version 3.0). The spectrums obtained from each isolate were imported to the Biotyper software, version 3.0 (Bruker Daltonics Gmb, Leipzig, Germany, version 3.3.1.0), and analyzed with using the database of reference spectrums of medically important bacteria. Values within the range of 2.300 and 3.000 , were considered a highly reliable identification of species; values between 2.000 and 2.999 were estimated as a reliable identification of a genus and a probable identification of species; values between 1.700 and 1.999 were considered as a probable identification of a genus; and values below 1.7 were considered an unreliable identification.

The antibiotic sensitivity of the bacteria and microscopic fungi was identified by the disc diffusion method according to Order No. 167 of the Ministry of Public Health of Ukraine of 05/04/2007 and EUCAST (European Committee on Antimicrobial Susceptibility Testing).

Determination of the density of the obtained biofilms. Into sterile disposable Petri dishes were introduced $5 \mathrm{~cm}^{3}$ of meat-peptone broth and $1 \mathrm{~cm}^{3}$ of daily test-culture of microorganisms in the concentration of $10^{5} \mathrm{CFU} / \mathrm{cm}^{3}$ and incubated at the temperature of $37^{\circ} \mathrm{C}$ for $24-48$ hours. Following the incubation, the dishes were three times cleaned off the plankton (floating) microorganisms with a phosphate buffer, dried off, and the resulting biofilms were fixed with $96^{\circ}$ ethyl alcohol for 10 minutes. Then they were dyed for 10 minutes with a $0.1 \%$ solution of crystal violet. $3.0 \mathrm{~cm}^{3}$ of 96 -percent ethyl alcohol was poured into the Petri dishes and left for 20-30 min, and stirred regularly. The optical density of the alcoholic solution was measured spectrophotometrically at $570 \mathrm{~nm}$ wave length [22]. In case of optical density (OD) of the scrub solution from biofilms up to 0.50 OD units, the density of the formed biofilms was considered low; from 0.51 up to 1.00 OD units - intermediate; and above 1.01 OD units - high [14].

DNA extraction. Bacterial strains of Staphylococcus aureus were cultivated in $5 \mathrm{ml}$ TSB (tryptic soy broth) for $24 \mathrm{~h}$ at $37^{\circ} \mathrm{C}$ with continuous shaking at $130 \mathrm{rpm}$ (New Brunswick Classic C2 Platform Shaker). The bacterial genomic DNA was extracted with a High Pure PCR Template Preparation Kit (Roche) according to the manufacturer protocol. The DNA concentration and purity were determined spectrophotometrically by measuring A260 and A280 using NanoDrop 8000 Spectrophotometer (Thermo Scientific). The genomic DNA samples were stored at $-20{ }^{\circ} \mathrm{C}$ until use. The genes associated with biofilm formation were determined with specific primers as listed in Table 1 . The primers used for the PCR were selected from the sequence data library or designed to facilitate the concomitant amplification of all putative PCR products in a single reaction. Therefore, all oligonucleotide had similar melting temperatures of approximately $61{ }^{\circ} \mathrm{C}$ and yielded PCR products of 75 to $211 \mathrm{bp}$ (Table 1).

The presence of ica $A$, icaD, icaC, icaB, agrA, srtA genes was detected by two multiplex polymerase chain reactions (mPCR). The $16 S$ rRNA gene and icaR gene were amplified by a separate PCR. mPCR amplification was performed using $20 \mu \mathrm{L}$ of a reaction mixture containing DreamTaq Green Master Mix (2X) (Thermo Scientific), $0.25 \mu \mathrm{M}$ of each primer and $10 \mathrm{ng}$ of the template DNA.

The concetration of primers in the 16S rRNA and icaR determination in a separate PCR was $0.5 \mu \mathrm{M}$. The PCR reaction was carried out in a thermocycler (Mastercycler nexus, Eppendorf) using the following program: the initial step at $95{ }^{\circ} \mathrm{C}$ for 3 min and 35 cycles at $95^{\circ} \mathrm{C}$ for $30 \mathrm{~s}, 61^{\circ} \mathrm{C}$ for $30 \mathrm{~s}$ and $72{ }^{\circ} \mathrm{C}$ for $15 \mathrm{~s}$; the final extension step at $72{ }^{\circ} \mathrm{C}$ for $10 \mathrm{~min}$ was added.

ISSN 1996-4536 (print) • ISSN 2311-0783 (on-line) • Біологічні Студії / Studia Biologica • 2020 • Том 14/№3 • С. 49-64 


\section{Table 1. Primers used for PCR}

\section{Таблиця 1. Праймери, використані для ПЛР}

\begin{tabular}{|c|c|c|}
\hline Genes & Nucleotide sequence of primers $\left(5^{\prime}-3^{\prime}\right)$ & Amplicon size (bp) \\
\hline $\begin{array}{l}\text { icaA } \\
\text { (Intercellular adhesion) }\end{array}$ & $\begin{array}{l}\text { F: CTTGCTGGCGCAGTCAATAC } \\
\text { R: GTAGCCAACGTCGACAACTG }\end{array}$ & 75 \\
\hline $\begin{array}{l}\text { icaD } \\
\text { (Intercellular adhesion) }\end{array}$ & $\begin{array}{l}\text { F: ACCCAACGCTAAAATCATCG } \\
\text { R: GCGAAAATGCCCATAGTTTC }\end{array}$ & 211 \\
\hline $\begin{array}{l}\text { icaC } \\
\text { (Intercellular adhesion) }\end{array}$ & $\begin{array}{l}\text { F: CTTGGGTATTTGCACGCATT } \\
\text { R: GCAATATCATGCCGACACCT }\end{array}$ & 209 \\
\hline $\begin{array}{l}\text { icaB } \\
\text { (Intercellular adhesion) }\end{array}$ & $\begin{array}{l}\text { F: ATACCGGCGACTGGGTTTAT } \\
\text { R: ATCCAAATCGTGGGTATGTGT }\end{array}$ & 141 \\
\hline $\begin{array}{l}\text { agrA } \\
\text { (Gene expression regulator) }\end{array}$ & $\begin{array}{l}\text { F: TCGTAAGCATGACCCAGTTG } \\
\text { R: AAATCCATCGCTGCAACTTT }\end{array}$ & 96 \\
\hline $\begin{array}{l}\text { srtA } \\
\text { (Gene encoding sortase A) }\end{array}$ & $\begin{array}{l}\text { F: GTGGTACTTATCCTAGTGGCAGC } \\
\text { R: GCCTGCCACTTTCGATTTATC }\end{array}$ & 183 \\
\hline $\begin{array}{l}\text { 16S_rRNA } \\
\text { (Internal standard gene) }\end{array}$ & $\begin{array}{l}\text { F: CTACAATGGACAATACAAAGGGC } \\
\text { R: TCACCGTAGCATGCTGATCT }\end{array}$ & 141 \\
\hline $\begin{array}{l}\text { icaR } \\
\text { (Intercellular adhesion regulator) }\end{array}$ & $\begin{array}{l}\text { F: TTTTCGACATCGAAGAAAGG } \\
\text { R: TTCCAGAAAATTCCTCAGGC }\end{array}$ & 72 \\
\hline
\end{tabular}

The amplified fragments were visualized by electrophoresis in $2.5 \%$ agarose gel stained with GoodView ${ }^{\mathrm{TM}}$ Nucleic Acid Stain (Ecoli). The results were captured with digital imaging system (Kodak Gel Logic 100, Kodak). The PCR probe containing DNA of S. aureus strain CNN 4223 and all PCR components was used as a positive control. The PCR probe that included sterile water and all PCR components was used as a negative control.

\section{RESULTS AND DISCUSSION}

The results of our previous study [15] showed that during periodontitis, dysbacteriosis characterized by a growing number of opportunistic microorganisms was formed in the oral cavity. In particular, dysbiotic changes were observed in all 180 periodontitis patients investigated. At the same time, an increase in the population level of the microorganism association was detected in $81 \%$ of cases; in $46 \%$ of cases, these associations consisted of two species of microorganisms, and in $35 \%$ they consisted of three species of microorganisms. In $73 \%$ of cases, bacteria of Staphylococcus genus were isolated both in the monoifection and in the structure of microbial associations.

The analysis of the taxonomic structure of microbial associations under periodontitis showed that in $73 \%(131 / 180)$ of cases Staphylococcus genus bacteria were represented by the following six species: S. aureus, S.haemolyticus, S. saprophyticus, S. epidermidis, S. xelosus and $S$. hominis, which had been isolated from the nidus of the inflammatory process. S. aureus was isolated from 58 patients; 16 of those isolates were methicillin-resistant. In the case of domination of microbial associations of opportunistic microorganisms in the oral cavity, clinical features of the disease were better expressed and correlated with clinical manifestations of the inflammatory process and dystrophic changes of the mucous membrane. 
It was established that under a chronic persisting inflammatory process, associations of opportunistic microorganisms dominated in the oral cavity of patients suffering from periodontitis. The analysis of the taxonomic structure of the isolates proved the domination of Staphylococcus genus bacteria. In the case of mono-infection, 19 isolates of Staphylococcus genus bacteria were collected; the others (112) were isolated within associations. Microorganisms isolated from patients with the most acute symptoms of the disease are presented in Table 2. It is noteworthy that Staphylococcus genus bacteria were present in all associations. The most frequently isolated bacteria were $S$. aureus + E. faecalis, S. haemolyticus + E. cloacea, S. aureus + E. faecalis + C. albicans, S. epidermidis + E. cloacea, etc.

Table 2. Formation of biofilms by Staphylococcus genus bacteria, isolated from the oral cavity of patients suffering from periodontitis, absolute number of isolates, $n=131$

Таблиця 2. Формування біоплівки бактеріями роду Staphylococcus, ізольованих із ротової порожнини хворих з пародонтитом, кількість ізолятів, $\mathrm{n}=131$

\begin{tabular}{l|c|c|cc|}
\hline Microorganisms & Non-biofilm-forming & $\begin{array}{c}\text { Number of microorganisms that formed bioflim } \\
\text { with the indicated density: } \\
\text { moderate }\end{array}$ & high \\
\hline S. aureus & 7 & 0 & 3 & 48 \\
S. haemolyticus & 8 & 0 & 7 & 29 \\
S. saprophyticus & 7 & - & - & - \\
S. epidermidis & 8 & 0 & 2 & 10 \\
S. xelosus & 1 & - & - & - \\
S. hominis & 1 & - & - & -
\end{tabular}

The identification showed that the isolated bacteria of Staphylococcus genus belonged to the following six species: S. aureus, S. haemolyticus, S. saprophyticus, S epidermidis, S. xelosus and S. hominis. Representatives of $S$. aureus species were isolated from 58 patients, 16 of those isolates were methicillin-resistant; in associations with other opportunistic microorganisms were isolated 45 strains of $S$. aureus.

The analysis of antibiotic susceptibility of the representatives of Staphylococcus genus showed the following percentage of resistance (Fig. 1, Fig. 2).

The analysis of susceptibility to $\beta$-lactam antibiotics revealed the highest level of resistance to ampicillin and amoxicillin. The highest percentage of susceptibility was observed to amoxicillin/clavulonate. Staphylococcus genus bacteria demonstrated high resistance to the group of macrolides, especially erythromycin, clarithromycin and azithromycin. The same tendency was observed for tetracyclines.

For staphylococci, the highest level of susceptibility was observed against phthorchinolons, especially levofloxacin, ofloxacin and gatifloxacin. The resistance of Staphylococcus genus bacteria to cephalosporins was as follows (Figs 1-2). A high level of the isolates resistance to such first and second generation cephalosporins as cefazolin, cephalexin and cefuroxime was observed. Species of Staphylococcus genus bacteria, were most susceptible to the third generation cefalosporins, such as ceftriaxone, cefixime and cefotaxime, and to the fourth generation cephalosporins: cefoperazone/sulbactam and ceftazidime $-12 \%$.

ISSN 1996-4536 (print) • ISSN 2311-0783 (on-line) • Біологічні Студії / Studia Biologica • 2020 • Том 14/№3 • С. 49-64 


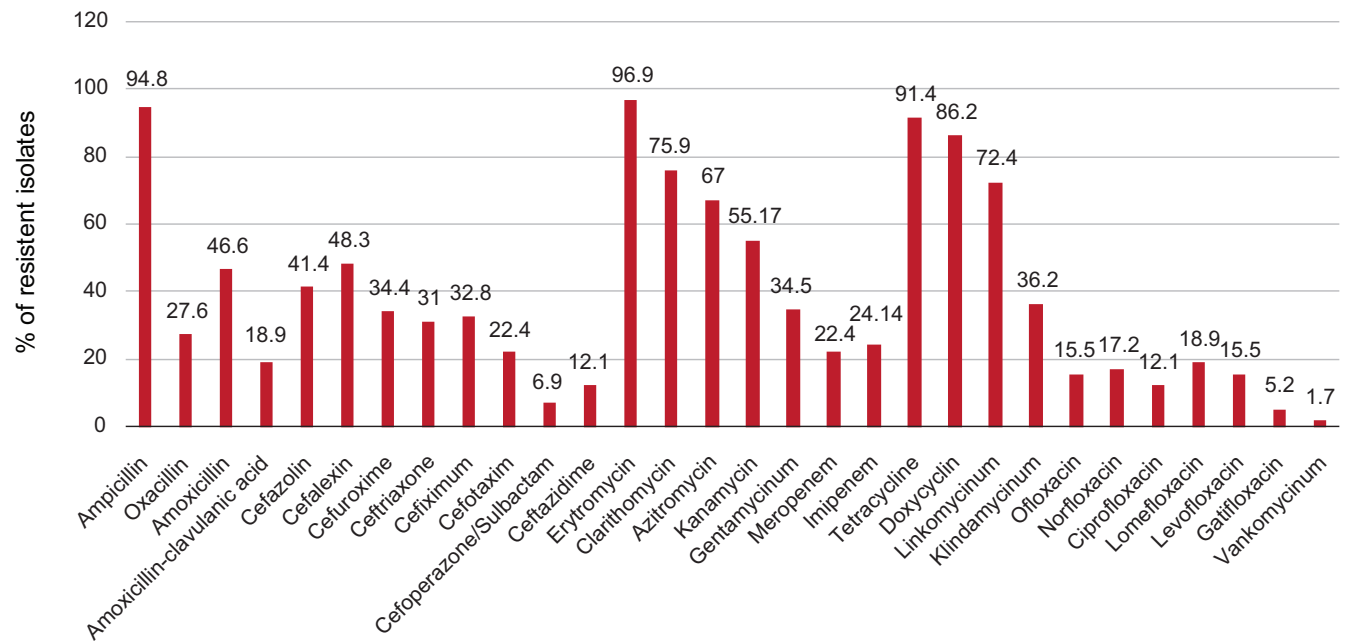

Fig. 1. Antibiotics resistance levels of coagulase-positive species of Staphylococcus genus bacteria isolated under conditions of periodontitis

Рис. 1. Рівень антибіотикорезистентності коагулазопозитивних видів бактерій роду Staphylococcus, ізольованих в умовах пародонтиту

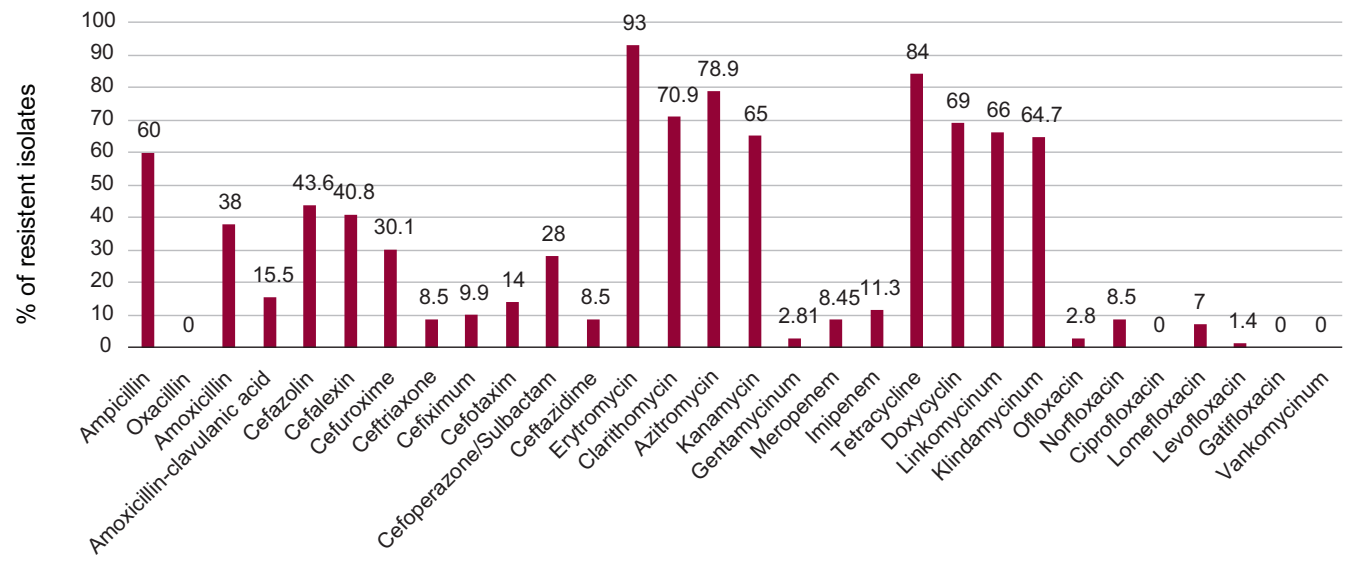

Fig. 2. Antibiotics resistance levels of coagulase-negeitive species of Staphylococcus genus bacteria isolated under conditions of periodontitis

Рис. 2. Рівень антибіотикорезистентності коагулазонегативних видів бактерій роду Staphylococcus, ізольованих в умовах пародонтиту

The comparative analysis of susceptibility to antibiotics of coagulase-positive and coagulase-negative species of Staphylococcus genus bacteria showed that the percentage of resistant isolates was lower among the coagulase-negative isolates. In particular, no strains resistant to oxacillin or gatifloxavin were identified among the coagulase-negative strains. It was found that $31 \%$ of the coagulase-positive strains were resistant to ceftriaxone, whereas this percentage among the coagulase-negative strains was only $8.5 \%$. Besides, $15.5 \%$ of $S$. aureus isolates proved resistant to ofloxacin, while among the coagulase-negative strains the share of ofloxacin-resistant strains was only $2.8 \%$.

Resistance to carbapenems was low, but the share of resistant isolates was higher by $10 \%$ among the coagulase-positive isolates.

ISSN 1996-4536 (print) • ISSN 2311-0783 (on-line) • Біологічні Студії / Studia Biologica • 2020 • Том 14/№3 • C. 49-64 
Over $60 \%$ of the isolates - both coagulase-positive and coagulase-negative were resistant to linkozamins and tetracyclines.

The highest level of susceptibility of Staphylococcus genus bacteria was established to fluoroquinolones and cephalosporins: cefoperazone/sulbactam, ceftazidime, ceftriaxone; among betalactamines - to amoxicillin/clavulonate.

One of the factors that potentiates the formation of antibiotic resistance is biofilm formation by bacteria. Both coagulase-positive and coagulase-negative species of Staphylococcus genus bacteria are known to form biofilms.

We isolated 51 bioflim-forming strains of $S$. aureus, 36 strains of $S$. haemolyticus, 12 strains of $S$. epidermidis from the oral cavity of patients with inflammatory periodontitis. $99(75.6 \%)$ out of 131 isolated strains had a biofilm-forming potential (Table 2). In addition, most of them were part of microbial associations. A prevailing majority of the isolates formed high-density biofilm; e.g., out of 51 strains of $S$. aureus, 48 formed highdensity biofilm $(3.95 \pm 0.15)$ (Table 3 ). Among the $S$. epidermidis, 10 isolates formed high-density and only two - moderate-density biofilm.

Table 3. Optical density of the suspension of biofilm forming bacteria of Staphylococcus genus, isolated from patients suffering from periodontitis, $M \pm m, n=131$

Таблиця 3. Оптична густина суспензії біоплівкотвірних бактерій роду Staphylococcus, ізольованих у пацієнтів 3 пародонтитом, $M \pm m, n=131$

\begin{tabular}{|l|c|c|c|}
\hline \multirow{2}{*}{ Microorganisms } & \multicolumn{3}{c|}{ Density of biofilm forming, OD $(\lambda=570 \mathrm{~nm}), \mathrm{M} \pm \mathrm{m}$} \\
\hline S. aureus & low & moderate & high \\
\hline S. haemolyticus & $1.50 \pm 0.05$ & $2.90 \pm 0.3$ & $3.95 \pm 0.15$ \\
\hline S. epidermidis & 0 & $2.75 \pm 0.25$ & $3.90 \pm 0.10$ \\
\hline S. xelosus & 0 & $2.85 \pm 0.10$ & $3.85 \pm 0.20$ \\
\hline S. hominis & - & - & - \\
\hline
\end{tabular}

We selected 10 isolates with a high level of resistance to antimicrobial preparations (resistant to 10 and more antibiotics), performed their chemotaxonomic identification and analysis of the genes associated with biofilm formation: 1, 3-5, 7-10 - biofilm forming $S$. aureus 2, 6 - non-biofilmforming $S$. aureus.

It was established that all $S$. aureus isolates possessed genetic determinants that are connected with ica $A$, icaB, icaC, icaD and icaR biofilm-forming potential. Lack of genes responsible for biofilm formation was established for two strains of $S$. aureus that did not form biofilm in polystyrene (Figs 3-6).

Opportunistic allochthonous microbiota are characterized by a high resistance level to antibacterial preparations at the background of a chronic inflammatory process chronic periodontitis. Biofilm formation by microorganisms referred to agents of opportunistic infections substantially aggravates the course of the inflammatory process and makes it difficult to treat due to the limited bioavailability of antimicrobial preparations and the formation of antibiotic resistance [15]. We investigated that under chronic generalized periodontitis, opportunistic microbial associations dominated in the microbiocoenosis of the oral cavity; in addition to that, in a prevailing majority of cases Staphylococcus genus bacteria were present in associations. It was found that $75.6 \%$ of the isolates

ISSN 1996-4536 (print) • ISSN 2311-0783 (on-line) • Біологічні Студії / Studia Biologica • 2020 • Том 14/№3 • C. 49-64 
of staphylococci were biofilm-forming. At the same time, the biofilm-forming isolates were extra-antibiotic-resistant. We selected 10 isolates characterized by a high resistance level to antibiotics, and detected the genes associated with biofilm formation. It was demonstrated that eight of them had all identified genes in their genome.

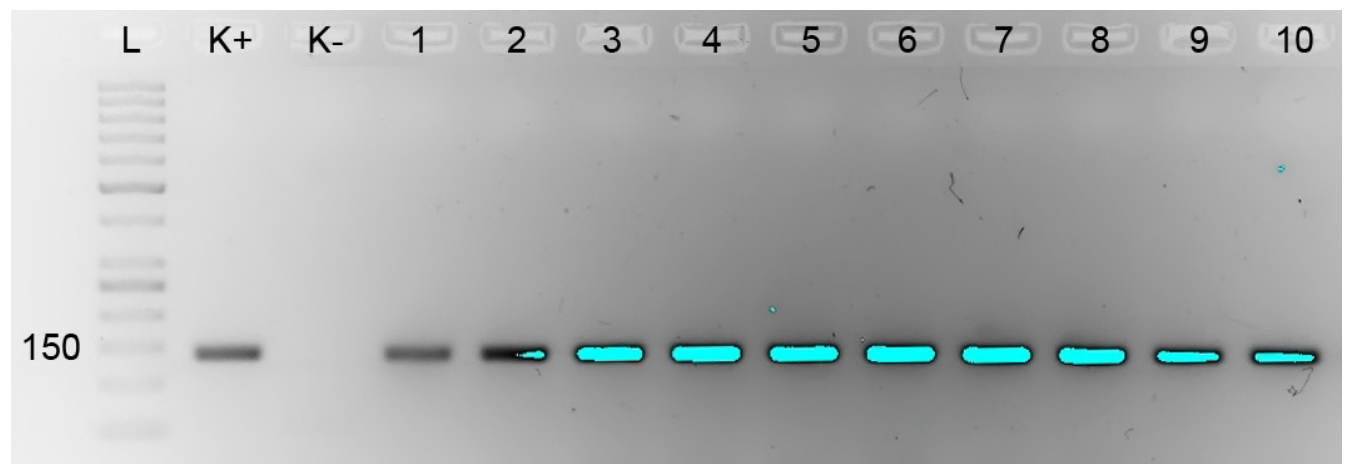

Fig. 3. Visualization of the amplified DNA fragments of $16 S$ rRNA gene (141 bp) of $S$. aureus isolates (lanes $1-10)$ from the oral cavity of patients with inflammatory disease. "K+" - S. aureus CNN 4223 - positive isolate; "K-" - negative control; L- = 50 bp DNA ladder

Рис. 3. Візуалізація ампліфікованих ДНК фрагменів $16 S$ rRNA гена (141bp) в ізолятів $S$. aureus (лінії 1-10) із ротової порожнини хворих з запальними захворюваннями. "K+" - S. aureus CNN 4223 позитивний контроль; “K-" - негативний контроль; L- = 50 bp DNA ladder

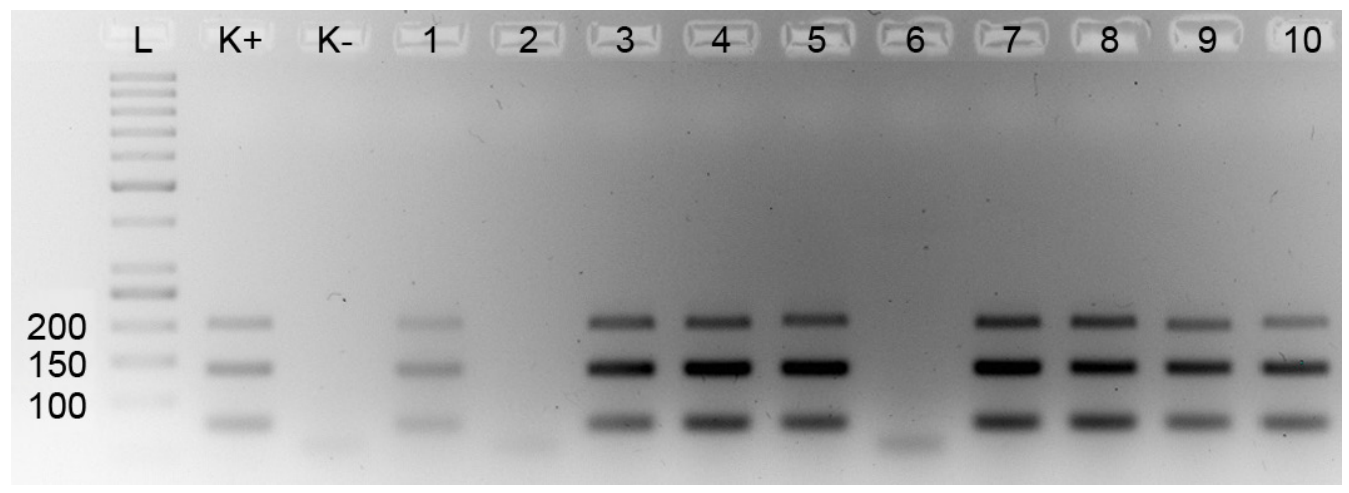

Fig. 4. Visualization of the amplified DNA fragments of icaA (75 bp), icaB (141 bp) and icaC (209 bp) genes of $S$. aureus isolates (lanes 1-10) from the oral cavity of patients with inflammatory disease. "K+" S. aureus CNN 4223 - positive isolate; "K-" - negative control; L- = 50 bp DNA ladder

Рис. 4. Візуалізація ампліфікованих ДНК фррагментів ісаA (75 bp), ісаB (141bp) та ісаC (209bp) генів у ізолятів $S$. aureus (лінії 1-10) із ротової порожнини хворих з запальними захворюваннями. "K+" - S. aureus CNN 4223 - позитивний контроль; "K-" - негативний контроль; L- = 50 bp DNA ladder

It was experimentally proven that biofilm formation is controlled by a number of genes, however, their role has not been fully clarified so far. Changes of gene expression during biofilm formation coordinated the formation of the structure, and the rise of antimicrobial tolerance [13]. In that case, the changes in gene expression were coordinated by specific signal molecules. The presence of such molecules activated, and then suppressed the genes that controlled virulence factors. It was established that

ISSN 1996-4536 (print) • ISSN 2311-0783 (on-line) • Біологічні Студії / Studia Biologica • 2020 • Том 14/№3 • C. 49-64 
Staphylococcus genus bacteria are an etiological factor of chronic persisting processes for humans and animals [13, 16].

We showed for the first time that $S$. aureus isolated from the oral cavity affected by periodontitis had both the phenotypic signs of the forming biofilm and the associated biofilm-forming genes. As most microorganisms in the oral cavity are part of the biofilm, our results may indicate that $S$. aureus bacteria play a significant role in the formation of oral biofilm in conditions of oral cavity dysbacteriosis under periodontitis. The presence of opportunistic microorganisms in the biofilm structure may play a significant role in the formation of antibiotic-resistant populations of staphylococci.

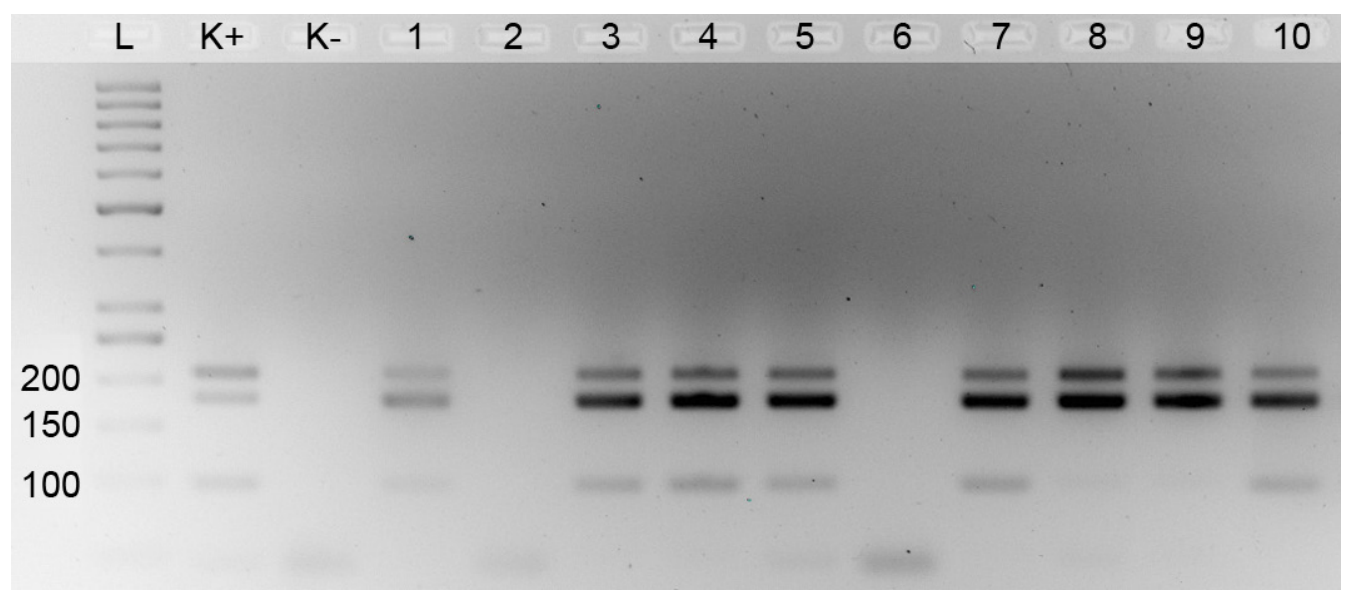

Fig. 5. Visualization of the amplified DNA fragments of icaD (211 bp), srtA (183 bp), agrA (96 bp) genes of S. aureus isolates (lanes 1-10) from the oral cavity of patients with inflammatory disease. "K+" S. aureus CNN 4223 - positive isolate; "K-" - negative control; L- = 50 bp DNA ladder

Рис. 5. Візуалізація ампліфікованих ДНК фррагментів генів ісаD (211bp), srtA (183 bp), agrA (96 bp) у ізолятів $S$. aureus (лінії 1-10) із ротової порожнини хворих з запальними захворюваннями. "K+" S. aureus CNN 4223 - позитивний контроль; "K-" - негативний контроль; L- = 50 bp DNA ladder

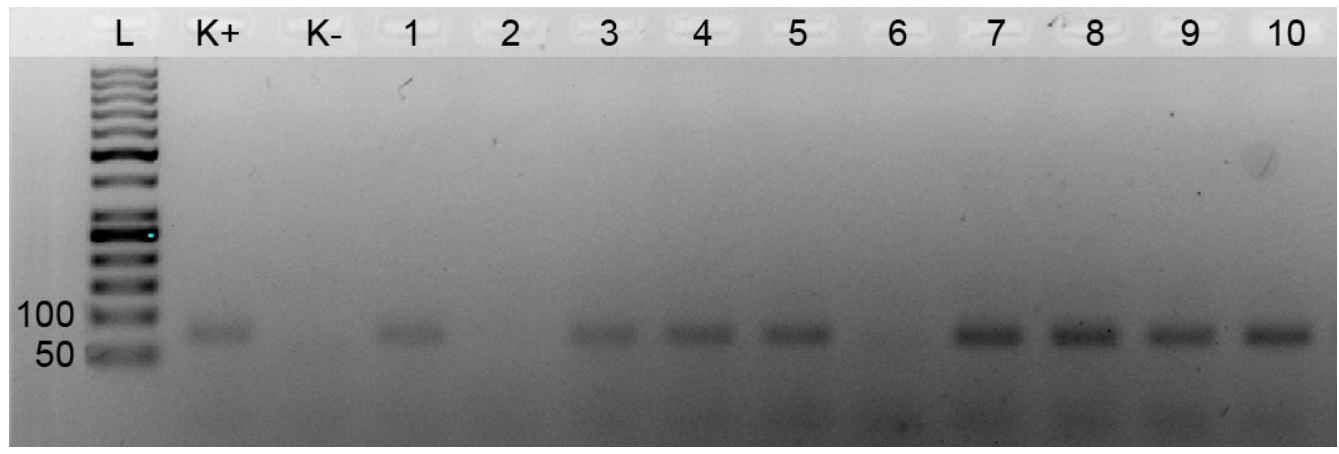

Fig. 6. Visualization of the amplified DNA fragments of icaR gene S.aureus isolates (lanes 1-10) from the oral cavity of patients with inflammatory disease. "K+" - S. aureus CNN 4223 - positive isolate; "K-" negative control; L - = 50 bp DNA ladder

Рис. 6. Візуалізація ампліфікованих ДНК фррагментів ісаR гена у ізолятів S. aureus (лінії 1-10) із ротової порожнини хворих з запальними захворюваннями. "K+" - S. aureus CNN 4223 - позитивний контроль; "K-" - негативний контроль; L- = 50 bp DNA ladder

ISSN 1996-4536 (print) • ISSN 2311-0783 (on-line) • Біологічні Студії / Studia Biologica • 2020 • Том 14/№3 • С. 49-64 
The formation of bacterial biofilm by Staphylococcus genus bacteria is a sophisticated process controlled by a variety of genes. Recent works have shown that Ica operon is usually found in biofilm-forming bacteria [10], and it is directly related to the formation of bacterial biofilm as its important factor. The operon consists of four genes (icaA, icaD, icaB and icaC); the product of their expression is Polysaccharide Intercellular Adhesion protein (PIA) that plays a considerable part in Staphylococcus adhesion during biofilm formation [9, 13]. This work also showed that among the 116 isolated bacteria of Staphylococcus genus, 41 strains had icaAD genes, and 51 strains - icaBC genes.

During the biofilm-forming process, the development of the mature stage of biofilm mainly depends upon polysaccharide adhesion, which is a prerequisite for accumulation of bacteria. The ica ADBC operon takes part in biofilm formation by coding the enzymes participating in PIA synthesis. Besides, the following genes take part in the process: the regulatory gene (sar), the additional regulatory gene (agr) and $\operatorname{sig} B$ [3]. The agglutinating factor (Clfa) and fibronectin-binding proteins (Fnbp) mediate the bacterial integration.

PIA biosynthesis is performed by the products of the ica gene locus responsible for expression of $\mathrm{N}$-acetylglucosamine transferase (icaA i icaD), and PIA diacetylase (icaB) $[3,10,18]$. The ica gene locus expression is regulated by a significant number of factors and regulatory proteins. It points to the correlation between the presence of ica $A$ and ica $D$ genes and their biofilm-forming potential. It was established that icaD plays a considerable role in the maximum expression of $\mathrm{N}$-acetylglucosamine transferase, which results in the expression of capsule polysaccharide $[9,25]$. The sig $B$, sar and agr genes also fulfill important functions in the processes of bacterial activity. Mutations in this sector lead to a substantial decrease in ica operon expression and PIA synthesis intensity [26].

The work [19] described an analysis of 176 isolates of coagulase-negative bacteria of Staphylococcus genus. It was established that $S$. epidermidis isolates with icaAD genes expression had a low degree of adhesion, while those with icaACD expression were characterized by a high degree of adhesion. Thus, the study showed that the isolates with three expressed genes were highly virulent due to producing Polysaccharide Intercellular Adhesion protein (PIA). It was found that the presence of one gene was not sufficient to form biofilm. Expression of icaA caused a weak fermentative activity and an insignificant amount of PIA. The presence of $i c a D$ gene product promoted polysaccharide biosynthesis. Expression of icaAD or icaACD intensified biofilm formation. At the same time, it is probable that icaB determined diacetylase when forming PIA. In that case, even if these genes are expressed, biofilm can be formed only as a subject to their expression. The experiment showed that of the 176 studied strains only 41 strains expressed icaAD, and of the 116 biofilm-positive strains only 51 strains expressed icaBC [13].

Another study established that the percentage of availability of icaA, icaB, icaC and icaD in S. aureus isolates equaled $51.6 \%, 45.1 \%, 77.4 \%$ and $80.6 \%$, respectively. In $12(38.7 \%)$ isolates, all biofilm genes were positive [21]. It was also found that the icaR gene encodes a transcriptional repressor involved in the environmental regulation of ica operon expression and biofillm formation in S. epidermidis [7, 18].

ISSN 1996-4536 (print) • ISSN 2311-0783 (on-line) • Біологічні Студії / Studia Biologica • 2020 • Том 14/№3 • C. 49-64 


\section{CONCLUSIONS}

Under conditions of generalized periodontitis, the domination of opportunistic microorganisms in the patients' oral cavity has been established. It is worth noting that bacteria of Staphylococcus genus were present in all associations. The most frequently isolated strains were S. aureus + E. faecalis, S. haemolyticus + E. cloacea, S. aureus + E. faecalis + C. albicans, S. epidermidis + E. cloacea, etc. The analysis of the taxonomic structure of microbial associations under periodontitis showed that in $73 \%(131 / 180)$ of cases were isolated Staphylococcus genus bacteria represented by the following six species: S. aureus, S. haemolyticus, S. saprophyticus, S. epidermidis, S. xelosus, and S. hominis. S.aureus was isolated from 58 patients, of which 29 isolates were methicillin-resistant. The highest level of susceptibility of Staphylococcus genus bacteria was observed for fluoroquinolones and cephalosporins - to cephoperason/sulbactam, ceftazidimum and ceftriaxone; among betalactams - to amoxicillin/clavulanat. The analysis of the taxonomic structure of the isolates proved the domination of Staphylococcus genus bacteria.

From the oral cavity of patients with inflammable periodontal process, 51 biofilmforming strains of $S$. aureus, 36 biofilm-forming strains of $S$. haemolyticus, 12 biofilmforming strains of $S$. epidermidis were isolated. Out of the 131 isolates, $99(76,5 \%)$ had a biofilm-forming potential. In addition to that, most of them did not belong to microbial associations. It has been established that antibiotic-resistant biofilm-forming isolates of $S$. aureus possess genetic determinants connected with icaA, icaC, icaB, icaA, icaC, and icaB genes that define biofilm-forming potential. Lack of genes responsible for biofilm formation was established for two non-biofilm forming strains of $S$. aureus.

\section{CONFLICT OF INTEREST}

The authors declare that there is no potential conflict of interest with respect to the research, authorship, and/or publication of this article.

This publication was supported by the Slovak Research and Development Agency under the Contract No. APVV-15-0377

The work was carried out within the framework of the Academic Internship Program of M.S. Kryvtsova, Erasmus + Košice University of Veterinary Medicine and Pharmacy, Department of Microbiology and Immunology, under the topic "Use of antimicrobial properties of medicinal herbs and probiotic materials as an alternative means of antibiotic therapy".

\section{COMPLIANCE WITH ETHICAL STANDARDS}

Human Rights: All procedures performed in studies involving human participants were in accordance with the ethical standards of the institutional and/or national research committee and with the 1964 Helsinki declaration and its later amendments or comparable ethical standards.

ISSN 1996-4536 (print) • ISSN 2311-0783 (on-line) • Біологічні Студії / Studia Biologica • 2020 • Том 14/№3 • С. 49-64 
1. Al Jehani Y.A. Risk factors of periodontal disease: review of the literature. Int J Dent, 2014; 182513.

Crossref $\bullet$ PubMed $\bullet$ Google Scholar

2. Anwar H., Starp J.L., Costerton W.J. Establishment of aging biofilms: possible mechanism of bacterial resistance to antimicrobial therapy. Antimicrobial Agents and Chemotherapy, 1992; 36(7): 1347-1351.

Crossref $\bullet$ PubMed $\bullet$ Google Scholar

3. Arciola C.R., Campoccia D., Ravaioli S., Montanaro L. Polysaccharide intercellular adhesin in biofilm: structural and regulatory aspects. Front Cell Infect Microbiol, 2015; 5: 7.

Crossref $\bullet$ PubMed $\bullet$ Google Scholar

4. Bascones Martínez A., Figuero Ruiz E. Periodontal diseases as bacterial infection. Av Periodon Implantol, 2005; 17(3): 111-118.

Crossref $\bullet$ PubMed $\bullet$ Google Scholar

5. Bereket W., Hemalatha K., Getenet B., Wondwossen T., Solomon A., Zeynudin A., Kannan S. Update on bacterial nosocomial infections. Eur Rev Med Pharmacol Sci, 2012; 16(8): 1039-1044.

PubMed • Google Scholar

6. Conlon K.M., Humphreys H., O'Gara J.P. Regulation of icaR gene expression in Staphylococcus epidermidis. FEMS Microbiology Letters, 2002; 216(2): 171-177.

Crossref $\bullet$ PubMed $\bullet$ Google Scholar

7. Dancer S.J. Staphylococcus aureus antibiotic resistance. Clinical insights: Staphylococcus aureus antibiotic resistance. Future Medicine Ltd, 2014 Jul; 2-5.

Crossref $\bullet$ Google Scholar

8. Fowler V.G. Jr, Fey P.D., Reller L.B., Chamis A.L., Corey G.R., Rupp M.E. The intercellular adhesin locus ica is present in clinical isolates of Staphylococcus aureus from bacteremic patients with infected and uninfected prosthetic joints. Med Microbiol Immunol, 2001; 189(3): 127-31.

Crossref $\bullet$ PubMed $\bullet$ Google Scholar

9. Frank K.L., Patel R. Poly-N-acetylglucosamine is not a major component of the extracellular matrix in biofilms formed by icaADBC-positive Staphylococcus lugdunensis isolates. Infection and Immunity, 2007; 75(10): 4728-4742.

Crossref $\bullet$ PubMed $\bullet$ Google Scholar

10. Global Action Plan on Antimicrobial Resistance. Microbe Magazine, Anon 2015. 10(9), 354355.

Crossref

11. Grigoryan A.S., Grudyanov A.Y., Rabukhina N.A., Frolova O.A. Periodontal disease. Pathogenesis, diagnosis, treatment. M., 2004. 320 p. (In Russian)

12. Heller D., Silva-Boghossian C.M., do Souto R.M., Colombo A.P. Subgingival microbial profiles of generalized aggressive and chronic periodontal diseases. Arch Oral Biol, 2012; 57(7): 973-80.

Crossref $\bullet$ PubMed $\bullet$ Google Scholar

13. Joo H.-S., Otto M. Molecular basis of in vivo biofilm formation by bacterial pathogens. Chem Biol, 2012;19(12): 1503-1513.

Crossref $\bullet$ PubMed $\bullet$ Google Scholar

14. Kryvtsova M.V., Kostenko Y.Y. Dominant microbial associations of oral cavat periodontitis and features of their sensitivity to antibacterial drugs. Studia Biologica, 2020;14(1):51-62.

Crossref $\bullet$ Google Scholar

15. Kukhtyn M., Berhilevych O., Kravcheniuk K., Shynkaruk O., Horiuk Y., Semaniuk N. The influence of disinfectans on microbial biofilms of dairy equipment. Eastern-European Journal of

Enterprise Technologies, 2017; 5/11(89): 26-33.

Crossref $\bullet$ Coogle Scholar

ISSN 1996-4536 (print) • ISSN 2311-0783 (on-line) • Біологічні Студії / Studia Biologica • 2020 • Том 14/№3 • С. 49-64 
16. Kumar S., Tripathi M. Antibiotic resistant bacteria: A global menace. Virol Immunol J, 2017; 1(3): 000118.

Crossref $\bullet$ Google Scholar

17. Li Li. Analysis of biofilm formation and associated gene detection in Staphylococcus isolates from bovine mastitis. African Journal of Boitechnology, 2012; 11(8).

Crossref $\bullet$ Google Scholar

18. O'Toole G., Kaplan H.B., Kolter R. Biofilm formation as microbial development. Annu Rev Microbiol, 2000; 54: 49-79.

Crossref $\bullet$ PubMed $\bullet$ Google Scholar

19. Otto M. Staphylococcal Biofilms. Bacterial Biofilms. Springer Berlin Heidelber, 2008; 207-228. Crossref • PubMed $\bullet$ Google Scholar

20. Rampelotto R.F., Lorenzoni V.V., Silva D. da C., Coelho S.S., Wust V., Garzon L.R., Nunes M.S., Meneghetti B., Brites P. Ch., Hörner M., Hörner R. Assessment of different methods for the detection of biofilm production in coagulase-negative staphylococci isolated from blood cultures of newborns. Revista da Sociedade Brasileira de Medicina Tropical, 2018; 51(6): 761-767.

Crossref $\bullet$ PubMed $\bullet$ Google Scholar

21. Samojlenko A.V. Pathogenic importance of various periodontal microorganisms in development of immunologic and clinical disorders of patients suffering from generalized periodontitis. Ukrayinskyi stomatolohichnyi almanakh, 2001; 6: 44-47. (In Russian)

22. Satorres S.E., Alcaráz L.E. Prevalence of icaA and icaD genes in Staphylococcus aureus and Staphylococcus epidermidis strains isolated from patients and hospital staff. Cent Eur J Public Health, 2007; 15(2): 87-90.

PubMed • Google Scholar

23. Stepanović S., Vuković D., Dakić I., Savić B., Švabić-Vlahović M. A modified microtiter-plate test for quantification of staphylococcal biofilm formation. Journal of Microbiological Methods, 2000; 40(2): 175-179.

Crossref $\bullet$ PubMed $\bullet$ Google Scholar

24. Stubbings W., Labischinski $H$. New antibiotics for antibiotic-resistant bacteria. F1000 Biology Reports, 2009; 29:1

Crossref $\bullet$ PubMed $\bullet$ Google Scholar

25. Vuong C., Saenz H.L., Götz F., Otto M. Impact of agr quorumsensing system on adherence to polystyrene in Staphylococcus aureus. J Infect Dis, 2000; 182: 1688-1693.

Crossref $\bullet$ PubMed $\bullet$ Google Scholar

26. Yazdani R., Oshaghi M., Havayi A. Detection of icaAD gene and biofilm formation in Staphylococcus aureus isolates from wound infections. Iran J Public Health, 2006; 35(2): 25-28. Google Scholar

27. Zhang Yu-Zhi, Singh S. Antibiotic stewardship programmes in intensive care units: Why, how, and where are they leading us. World J Crit Care Med, 2015; 4(1): 13-28.

Crossref $\bullet$ PubMed $\bullet$ Google Scholar

ISSN 1996-4536 (print) • ISSN 2311-0783 (on-line) • Біологічні Студії / Studia Biologica • 2020 • Том 14/№3 • С. 49-64 


\title{
ВИЗНАЧЕННЯ БІОПЛІВКОУТВОРЕННЯ ТА ВИЯВЛЕННЯ АСОЦІЙОВАНИХ ГЕНІВ У ІЗОЛЯТІВ РОДУ STАРНYLOCOCCUS I3 РОТОВОÏ ПОРОЖНИНИ В УМОВАХ ЗАПАЛЬНИХ ЗАХВОРЮВАНЬ ПАРОДОНТУ
}

\author{
М. В. Кривцова ${ }^{1 *}$, Я. Кіралі , Я. Кощова", \\ Є. Я. Костенко ${ }^{3}$ Р. В. Бубнов ${ }^{4}$, М. Я. Співак \\ 1 Ужгородський національний університет \\ біологічний фракультет, кафредра генетики, фрізіології рослин і мікробіології \\ вул. Волошина, 32, Ужгород 88000, Україна \\ 2 Університет ветеринарії та фрармації, Кошице, Словакія \\ ${ }^{3}$ Ужгородський національний університет, кафредра ортопедичної стоматології \\ вул. Університетська, 16, Ужгород 88000, Україна \\ ${ }^{4}$ Інститут мікробіології і вірусології ім. Д. М. Заболотного НАН України \\ вул. Заболотного, 154, Київ МСП03680, Україна \\ *Кореспондуючий автор: e-mail: maryna.krivcova@uzhnu.edu.ua
}

Вступ. Стрімко зростаюча тенденція до фрормування антибіотикорезистентних штамів мікроорганізмів обумовлює актуальність робіт, спрямованих на моніторинг їхньої чутливості до антибіотиків. Запальні захворювання пародонту, зокрема, пародонтит, супроводжуються хронічним персистуючим запальним процесом, що потребує застосування антибактеріальних препаратів. Більшість мікроорганізмів ротової порожнини містяться у складі біоплівки. Хронічний запальний процес і здатність до біоплівкоутворення $є$ чинниками, що сприяють фрормуванню антибіотикорезистентних штамів мікроорганізмів.

Метою роботи було дослідити здатність до утворення біоплівки та наявність генів, асоційованих з утворенням біоплівки у антибіотикорезистентних біоплівкотвірних бактерій роду Staphylococcus, ізольованих із ротової порожнини хворих на пародонтит.

Матеріали і методи. Дослідження проведені на базі Ужгородського національного університету (Ужгород, Україна) та Кошицького університету ветеринарії та фармації (Кошице, Словакія). Виділення ізолятів проводили у хворих на хронічний пародонтит із використанням диференційно діагностичних поживних середовищ; ідентифікацію проводили з використанням ENTERO-test, STREPTO-test, STAPHYLO-test. Хемотаксономічну ідентифікацію антибіотикорезистентних ізолятів виконували на пристрої Microflex LT (Bruker Daltonics Gmb, Lipsko, Nemecko) Flex Control (verzia 3.0). Здатність до біоплівкоутворення вивчали способом культивування у пластикових чашках Петрі, з подальшим фрарбуванням біоплівки 0,1\% розчином кристал віолету та спектрометричним визначенням оптичної густини спиртового розчину після відмивання етиловим спиртом.

Чутливість бактерій до антибіотиків і мікроскопічних грибів визначали дискодифузійним методом відповідно до наказу Міністерства охорони здоров'я України від 16.04.2007 № 167 та EUCAST (Європейський комітет з тестування сприйнятливості до антимікробних препаратів). Наявність генів ica $A$, ica $D$, icaC, icaB, agrA, srtA виявляли за допомогою двох мультиплексних полімеразних ланцюгових реакцій (мПЛР). Ген $16 \mathrm{~S}$ pPHК і ген icaR ампліфіковано за допомогою окремої ПЛР.

ISSN 1996-4536 (print) • ISSN 2311-0783 (on-line) • Біологічні Студії / Studia Biologica • 2020 • Том 14/№3 • C. 49-64 
Результати. 3'ясовано, що в умовах пародонтиту у мікробоценозі ротової порожнини домінують умовно патогенні мікробні асоціації, у цьому разі в переважній більшості у структурі асоціацій наявні бактерії роду Staphylococcus. У 73 \% (131/180) випадків із осередку запального процесу виділяли бактерії роду Staphylococcus, представлені 6 видами: S. aureus, S. haemolyticus, S. saprophyticus, S. epidermidis, S. xelosus, S. hominis. Найвищий рівень чутливості бактерій роду Staphylococcus виявлений для фрторхінолонів і цефалоспоринів - цефоперазон/ сульбактаму, цефтазидиму, цефтріаксону; серед беталактамів - амоксацилін/клавулонату. Із ротової порожнини людей із запальним процесом пародонту ізольовано 51 біоплівкоутворюючий штам S. aureus, 29 - S. haemolyticus, 12 - S. saprophyticus i 12 - S. epidermidis. Із 131 ізолятів 104 (79 \%) ізольованих штамів були здатними до утворення біоплівки, більшість із них входили до складу мікробних асоціацій. Встановлено, що біоплівкотвірні ізоляти S. aureus мають генетичні детермінанти, з якими на сьогодні пов'язують здатність утворення біоплівки ісаA, icaC, icaB ісаA, icaR, agrA, srtA. Встановлено, що у двох полірезистентних ізолятів S. aureus, що не утворювали біоплівку, немає генів, які асоційовані зі здатністю до її формування.

Висновки. Встановлено, що у мікробіоценозі ротової порожнини у разі хронічного пародонту домінують мікробні асоціації, у складі яких переважають бактерії роду Staphylococcus, більшість з яких має здатність до утворення біоплівки та стійкість до ряду антибіотиків.

Ключові слова: антибіотикорезистентність, мікробні асоціації, бактерії роду Staphylococcus, біоплівкоутворення 